\title{
Influence of Temperature on Methane Output from Bog Sludge and Crushed Reed Raw Materials
}

\author{
Sergejs Osipovs \\ Department of Applied Chemistry \\ Daugavpils University \\ Daugavpils, Latvia \\ sergejs.osipovs@du.lv
}

\author{
Jeḷena Kirilova \\ Department of Applied Chemistry \\ Daugavpils University \\ Daugavpils, Latvia \\ jelena.kirilova@du.lv
}

\author{
Aleksandrs Pučkins \\ Department of Applied Chemistry \\ Daugavpils University \\ Daugavpils, Latvia \\ aleksandrs.puckins@du.lv \\ Juris Soms \\ Department of Environmental \\ Science and Chemistry \\ Daugavpils University \\ Daugavpils, Latvia \\ juris.soms@du.lv
}

\author{
Mihails Pupiņš \\ Department of Ecology \\ Daugavpils University \\ Daugavpils, Latvia \\ mihails.pupins@du.lv
}

\begin{abstract}
The research summarizes information on biochemical processes of biogas production and the parameters that affect the results of its production. The research examines the result of obtaining biogas from bog sludge and a mixture of crushed reed. Particular attention is given to temperature, as a parameter that affects the results of methane and biogas production.
\end{abstract}

The yield of biogas and methane during the bioprocess depends on the effect of temperature. During the experiment, $2.78 \mathrm{~L}$ of biogas with an average methane content of $38.7 \%$ was obtained from a mixture of bog sludge and crushed reeds. If the content of organic compounds in the sludge was higher, the biogas yield would increase during the process. It is more advantageous to use the raw material mixture for biogas production.

Keywords - Anaerobic fermentation, biogas, influence of temperature.

\section{INTRODUCTION}

Biogas is a gaseous energy resource that can be obtained by anaerobic fermentation (AF) using biomass. The main component of biogas is methane $\left(\mathrm{CH}_{4}\right)$ and carbon dioxide $\left(\mathrm{CO}_{2}\right)$, which also includes other gases with certain physical properties. Biogas is a renewable energy resource that does not pollute the environment and the air. Biogas production reduces landfill growth and reduces water and soil pollution. The trend of biogas technologies is improving every time, thus the supply for biogas production is increasing. Capital investment in biogas plants requires relatively low costs. Their use reduces the greenhouse effect, as decomposing products emit $\mathrm{CH}_{4}$ and $\mathrm{CO}_{2}$ gases, which trap infrared (thermal) radiation reflected from the earth's surface [1].

Unlike fossil fuels, biogas is a fully renewable resource because it is produced from biomass. Biogas will not only improve the country's energy balance, but will also make a major contribution to conserving natural resources and improving the environment.

Another major environmental challenge for modern society is the growing amount of waste. Controlled landfilling or incineration of organic waste is not best practice.

According to the Multiannual Strategic Guidelines for Aquaculture 2014-2020, it is known that the biggest problems for aquaculture are the large amount of waste from fish life processes, as well as the large amount of energy required for economic activity [2].

The production of biogas by anaerobic fermentation is considered to be the optimal solution for the recycling of various types of organic waste, converting this waste into renewable energy and organic fertilizers. 
Latvia has experience in biogas production in landfills and wastewater treatment plants, as well as attempts to produce biogas on farms. In turn, the production of biogas from aquaculture residues has not been studied and is currently not used in Latvia.

The uses of biogas are different, they provide electricity and heat production. Compared to other renewable energy sources, biogas is a permanent, regular source, so energy can be obtained all year round. Purified biogas is used as a vehicle fuel and can be fed into the common natural gas supply network. Combustion of biogas can produce carbon dioxide for use in greenhouses [3]. Biomethane, or enriched biogas, is used as a fuel because the calorific value of biomethane is relatively higher than that of other hydrocarbons [4]. By purifying biogas from $\mathrm{CO}_{2}$, its calorific value increases.

The AF process takes place in thermophilic $\left(55-70^{\circ} \mathrm{C}\right)$ or mesophilic $\left(32-45^{\circ} \mathrm{C}\right)$ temperature mode. It is important to maintain a constant temperature in the bioreactor, as methanogens, especially thermophilic methanogens, are very sensitive to temperature fluctuations. This is due to the fact that there are fewer thermophilic methanogenic microorganisms than mesophilic methanogens [5]. The thermophilic process has several advantages: it is characterized by a high metabolic rate, the destruction and elimination of the pathogen, and a high biogas yield. The disadvantages of the thermophilic process are the increase in volatile fatty acids, which results in an unstable yield of methane [6]. Hu, Kobayashi and co-authors [7] found in the study that methane yields are temperature dependent. Under mesophilic conditions, the yield of methane was higher than in thermophilic conditions.

Microorganisms need a certain amount of time to process the appropriate substrates. It is therefore important to determine, specify and select the appropriate exposure time (HRT) for each biochemical process in the AF phase. When HRT is not at optimal levels, metabolic adverse conditions occur. If the holding time is too long, the microorganisms die due to lack of nutrients. Conversely, if the HRT is too fast, the amount of volatile fatty acids increases and the yield of methane decreases.

Organic Loading Rate (OLR) is an operating parameter that shows how much organic solids can be fed to the bioreactor per $\mathrm{m}^{3}$ of volume and per unit time. If too much OLR is fed into the bioreactor, inhibitory substrates such as volatile fatty acids may accumulate. This situation reduces the outcome of $\mathrm{CH}_{4}$, because the acidic $\mathrm{pH}$ has a negative impact on the activity of microorganisms [8].

\section{MATERIALS AND METHODS}

\section{A. Biomass}

In order to perform the work and obtain biogas, bog sludge from Vilaka region, and bog reeds from Daugavpils Esplanāde park were used in, which were dried and divided into components: stems, leaves, flowers.
In order for anaerobic fermentation processes to be possible, digestate from the biogas plant "Skaista“, Daugava region, Skrudalienas parish was used.

\section{B. Laboratory scale bioreactor}

Bioreactor EDF-5.4_2 (manufactured by Biotehniskais centrs, Latvia) has a compact, ergonomic and robust design. Glass cylinder vessel is mounted between the upper lid and the metallic jacketed bottom. The design of the bioreactor is easy to maintain and apply basic operations and preparatory process, in particular, washing and autoclaving.

Gas mixing measurement was done using mass flow controllers Hamilton ARC pH and DO sensors. These sensors send 4-20 mA signals directly to process control system (PCS) and ensure at the same time information management via Bluetooth in smartphones or PC installed programs. This program generates a report about all calibration procedures, sterilization numbers, predicted service life. Connection of sensors: off-gas analysis $\mathrm{O}_{2}$, $\mathrm{CO}_{2}, \mathrm{CH}_{4}$.

On-line/off-line data analysis and advanced process control possibilities was carried out using PC implemented program (Matlab, Python) algorithms communicating to process control system (PCS and SCADA).

\section{Determination of sludge and reed moisture}

The sludge substance was mixed in a container with a metal spatula so that the moisture in the substrate was evenly distributed. Pieces of roots and other plant remains were removed from sludge by tweezers. A 10 g sample of substrate was weighed. The sample was placed in a humidity analyzer Mettler Toledo HB43-S with a drying temperature $105 \pm 2^{\circ} \mathrm{C}$ [9]. The moisture content of the substrate was determined and a dry residue was obtained. The moisture of 3 samples was determined for the accuracy of one study. The resulting dry residue was further used to determine the organic matter content. Similar procedures were done by the reed.

\section{Determination of sludge and reed organic matter content}

The empty crucibles were placed in a muffle furnace where they were heated to $550 \pm 10^{\circ} \mathrm{C}$ for at least 60 minutes. Then the crucibles were removed from furnace and placed on a heat-resistant surface for 5-10 minutes, subsequently after a while the crucibles were left to cool in a desiccator. The cooled crucible was weighed to the nearest $0.1 \mathrm{mg}$ on an analytical balance and weigh 1 to 2 $\mathrm{g}$ of the test sample was put into the crucible. The test sample was heated in a muffle furnace for two hours at $800 \pm 10^{\circ} \mathrm{C}$; after that placed in a cool desiccator. This procedure of heating and weighing was repeated to constant weight. The organic matter content was calculated as a percentage of the dry residue [10]. Similar procedures were done by the reed. 


\section{E. Preparation of the mixture for biogas production}

To the prepared 1,200 $\mathrm{g}$ of bog sludge was added $50 \mathrm{~g}$ of crushed reed powder and mixed thoroughly. The prepared mixture was thoroughly immersed in the reactor vessel and $300 \mathrm{~mL}$ of bog water was added, mixed thoroughly with a metal spatula. 1,000 g of digestat was added and was tightly sealed with a bioreactor lid. The appropriate temperature mode and agitator rotation speed are selected and connected to the bioprocess controller.

\section{F. Selected parameters of the bioprocess controller}

The following parameters were used in the bioprocess controller to perform the work:

- $\quad 38^{\circ} \mathrm{C}, 40^{\circ} \mathrm{C}$, and $42^{\circ} \mathrm{C}$ temperature mode;

- Agitator rotation speed interval $50 \mathrm{rpm}$;

- Foam level sensors.

A computer with SCADA (Supervisory control and data acquisition) software was connected to the bioreactor, which recorded the volume and composition analysis of the released biogas.

\section{RESULTS AND DISCUSSION}

\section{A. Determination of sludge and reed moisture and organic matter content}

The obtained moisture results of sludge samples are valid for biogas production, as the dry residue in substrate samples is about $15 \%$ (see Tab. 1). The results are in line with the type of wet fermentation, which is similar to the other potential biogas technology [11].

TABLE 1 SLUDGE AND REED MOISTURE AND ORGANIC MATTER CONTENT

\begin{tabular}{|l|c|c|}
\hline \multicolumn{1}{|c|}{ Biomass } & Moisture, \% & $\begin{array}{c}\text { Organic matter } \\
\text { content (from dry } \\
\text { matter), \% }\end{array}$ \\
\hline Sludge & $84.96 \pm 0.46$ & $27.31 \pm 0.42$ \\
\hline Reed & $1.26 \pm 0.22$ & $96.61 \pm 0.74$ \\
\hline
\end{tabular}

The amount of organic matter obtained from sludge samples is about $27 \%$, which indicates a high content of inorganic substances in the substrate. In order to obtain more biogas yield in the study, a relatively larger amount of bog sludge must be fed into the bioreactor, with the addition of another type of substrate in which the percentage of organic matter is about $90 \%$ or more.

The amount of organic matter obtained from reed samples is about $97 \%$, which indicates a high content of organic matter, so it is advantageous to add it to the bog sludge in a certain ratio. The improved mixture can then be used for biogas production.

\section{B. Biogas production}

During each experiment, the released volume of biogas and the gas composition in the obtained biogas were studied with the research software SCADA.

The Fig. 1 shows the trend in biogas volume release over 60 days at $38^{\circ} \mathrm{C}, 40^{\circ} \mathrm{C}$, and $42^{\circ} \mathrm{C}$.

Of the total biogas produced during the fermentation period (60 days), 95\% was produced from the $10^{\text {th }}$ to the $55^{\text {th }}$ day at all temperatures tested (see Fig. 1 ). The optimal retention time is about 35 days at temperature $40^{\circ} \mathrm{C}, 38$ days at $38^{\circ} \mathrm{C}$, and 33 days for at $42^{\circ} \mathrm{C}$. The mixing mode of the feed during the experiment prevents the formation of dry and inactive flotation layers and can influence the optimal retention time. In this study, more than $95 \%$ of biogas can be produced in less than two months.

The average concentration of methane in biogas resulting from $\mathrm{AF}$ at a temperature of $40^{\circ} \mathrm{C}$ is $38.7 \%$, carbon dioxide $-60.4 \%$, other gases $-0.9 \%$; from $\mathrm{AF}$ at a temperature of $38^{\circ} \mathrm{C}$ concentration of methane is $39.9 \%$, carbon dioxide is $59.3 \%$, other gases are $0.8 \%$; and from $\mathrm{AF}$ at a temperature of $42^{\circ} \mathrm{C}$ concentration of methane is $36.1 \%$, carbon dioxide $-63.1 \%$, other gases $-0.8 \%$.

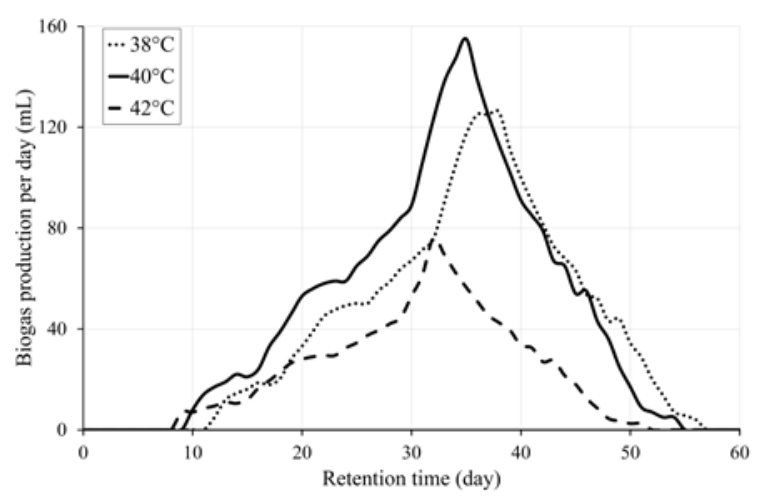

Fig. 1. Trend in biogas volume release over 60 days at different temperatures.

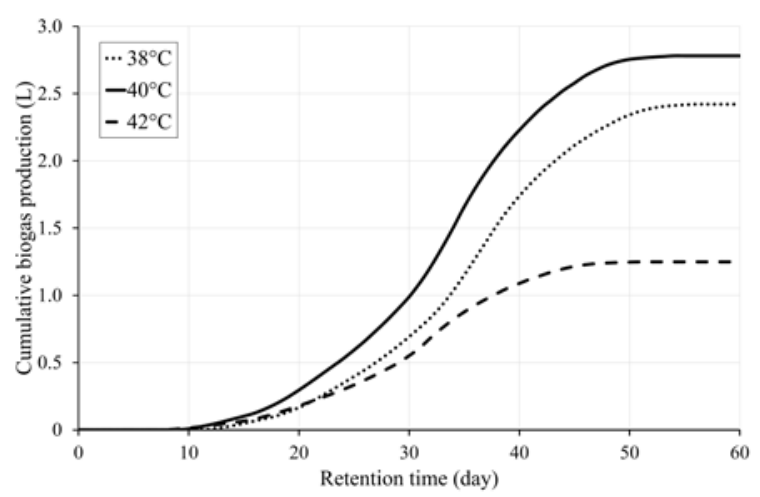

Fig. 2. Trend in cumulative biogas production over 60 days at different temperatures. 
For the three temperature, the average cumulative biogas production in $\mathrm{mL}$ was measured and recorded daily as shown in Fig. 2.

\section{CONCLUSIONS}

The biogas yield during the bioprocess depends on the effect of temperature, the best results in our study were obtained at a temperature of $40^{\circ} \mathrm{C}$.

During the experiment, 2.78 liters of biogas with an average methane content of $38.7 \%$ were obtained from a mixture of bog sludge and crushed reed at a temperature of $40^{\circ} \mathrm{C}$. If the organic matter content in sludge were higher, the biogas yield would increase during the process.

The proportion of methane in biogas was the best at a temperature of $38^{\circ} \mathrm{C}-39.9 \%$, but at this temperature regime the total volume of biogas turned out to be about $15 \%$ less.

The worst results were obtained at a temperature of $42^{\circ} \mathrm{C}$ - both in terms of the volume of biogas and the proportion of methane in it.

\section{ACKNOWLEDGMENTS}

This research was supported within the Daugavpils University internal research project competition (project "Biogas production possibility from aquaculture waste"; Nr. 14-95/2021/20).

\section{REFERENCES}

[1] S. Bhardwaj and P. Das, "A Review: Advantages and Disadvantages of Biogas” International Research Journal of Engineering and Technology, vol. 4 (10), pp. 890-893, October $2017 . \quad$ Available: IRJET, https://www.irjet.net/archives/V4/i10/IRJET-V4I10155.pdf [Accessed: March 31, 2021].

[2] "Akvakultūras daudzgadu stratēǵiskās pamatnostādnes 2014.2020. gadam”, 2013. [Online]. Available: https://www.zm.gov.lv/public/files/CMS Static Page Doc/00/00/ 00/35/82/akvakultura_2014.pdf [Accessed: March 31, 2021].

[3] A. Kalniņš, "Biogāzes iespējas un tās kā transportlīdzekḷu degvielas izmantošana", 2007. [Online]. Available: http://petijumi.mk.gov.lv/sites/default/files/file/EM Biogazes ies pejas un tas ka transportlidz degv izmantos 2007.pdf [Accessed: March 31, 2021].
[4] Z. Bagi, N. Ács, T. Böjti, B. Kakuk, G. Rákhely, O. Strang, M. Szuhaj, R. Wirth and K. L. Kovács, "Biomethane: The energy storage, platform chemical and greenhouse gas mitigation target" Anaerobe, vol. 46, pp 13-22, August 2017. Available: ScienceDirect, https://www.sciencedirect.com/ [Accessed: March 31, 2021], https://doi.org/10.1016/j.anaerobe.2017.03.001

[5] S. Mirmohamadsadeghi, K. Karimi, M. Tabatabaei and M. Aghbashlo, "Biogas production from food wastes: A review on recent developments and future perspectives" Bioresource Technology Reports, vol. 7, 100202, September 2019. Available: ScienceDirect, https://www.sciencedirect.com/ [Accessed: March 31, 2021], https://doi.org/10.1016/j.biteb.2019.100202

[6] P. Wang, H. Wang, Y. Qiu, L. Ren and B. Jiang, "Microbial characteristics in anaerobic digestion process of food waste for methane production-A review" Bioresource Technology, vol. 248 (Part A), pp. 29-36, January 2018. Available: ScienceDirect, https://www.sciencedirect.com/ [Accessed: March 31, 2021], https://doi.org/10.1016/j.biortech.2017.06.152

[7] Y. Hu, T. Kobayashi, W. Qi, H. Oshibe and K. Xu, "Effect of temperature and organic loading rate on siphon-driven self-agitated anaerobic digestion performance for food waste treatment" Waste Management, vol. 74, pp. 150-157, April 2018. Available: ScienceDirect, https://www.sciencedirect.com/ [Accessed: March 31, 2021], https://doi.org/10.1016/j.wasman.2017.12.016

[8] S. K. Pramanik, F. B. Suja, S.M. Zain and B.K. Pramanik, "The anaerobic digestion process of biogas production from food waste: Prospects and constraints” Bioresource Technology Reports, vol. 8, 100310, December 2019. Available: ScienceDirect, https://www.sciencedirect.com/ [Accessed: March 31, 2021], https://doi.org/10.1016/j.biteb.2019.100310

[9] S. Achinas and G. J. W. Euverink, "Theoretical analysis of biogas potential prediction from agricultural waste" Resource-Efficient Technologies, vol. 2, pp. 143-147, September 2016. Available: ScienceDirect, https://www.sciencedirect.com/ [Accessed: March 31, 2021], https://doi.org/10.1016/j.reffit.2016.08.001

[10] J. Kainthola, A. S. Kalamdhad and V. V. Goud, "A review on enhanced biogas production from anaerobic digestion of lignocellulosic biomass by different enhancement techniques" Process Biochemistry, vol. 84, pp. 81-90, September 2019. Available: ScienceDirect, https://www.sciencedirect.com/ [Accessed: $\quad$ March 31, https://doi.org/10.1016/j.procbio.2019.05.023

[11] T. Getahun, M. Gebrehiwot, A. Ambelu, T. Van Gerven and B. Van Der Bruggen, B, "The potential of biogas production from municipal solid waste in a tropical climate" Environmental Monitoring and Assessment, vol.186 (7), pp. 4637-4646, July 2014 Available: SpringerLink, https://link.springer.com/ [Accessed: March 31, 2021], https://doi.org/10.1007/s10661-014-3727-4 